Rev. Int. Contam. Ambie. 36 (4) 967-975, 2020

https://doi.org/10.20937/RICA.53674

\title{
THE MEXICAN AXOLOTL'S (Ambystoma mexicanum) EARLY DEVELOPMENT AND SURVIVAL IS AFFECTED BY COMMERCIAL GRADE MALATHION AND DICHLORVOS ORGANOPHOSPHORUS PESTICIDES
}

\author{
El desarrollo temprano y sobrevivencia del ajolote mexicano (Ambystoma mexicanum) \\ son afectados por los pesticidas organofosforados malatión y diclorvos de grado comercial \\ Yutzil Irene CASTÁN-AQUINO, Sandra Fabiola ARIAS-BALDERAS, Ernesto ROJO-SALINAS, \\ Edgar CERVANTES-RANGEL, Iram Alejandro RAMOS-TRUJILLO and Oscar Omar SOLÍS-CASTRO*
}

Facultad de Estudios Superiores Iztacala, Universidad Nacional Autónoma de México. Av. Los Barrios 1, Colonia Los Reyes Iztacala, 54090 Tlalnepantla, Estado de México, México.

*Author for correspondence: oscar_solis90@hotmail.com

(Received: July 2019; accepted: March 2020)

Key words: amphibian development, water pollution, conservation strategies, Xochimilco.

\begin{abstract}
The wild population of the Mexican axolotl (Ambystoma mexicanum) is subject to a dramatic decline as a consequence of deteriorating conditions in its natural habitat, Xochimilco. The common use of organophosphorus pesticides (OPPs) in the region affects water quality and is partially responsible for the axolotl decline. This could be a consequence of the delicate nature of axolotls, which are struggling to survive under contaminated conditions at early stages of development. In this regard, we aimed to extend the knowledge of OPPs effect on the survival of axolotls in their early stage of development, within the context of detrimental environment conditions using commercial grade OPPs. Fertilized axolotl eggs were treated with malathion (MLT), dichlorvos (DDVP), and a depurated group in which the OPPs exposure was stopped earlier, as well as an untreated control group. Changes in hatching, survival, size, and morphology were monitored and analyzed in embryos and early larvae. Our results showed that MLT and DVPP accelerate egg hatching and mortality even after the early removal of OPPs from the medium. OPPs also caused a reduced size and morphological abnormalities. It is proposed that such abnormalities would jeopardize the survival of the wildlife axolotl. Our results suggest that OPPs can cause irreversible damage to the axolotl embryos, stopping their normal development, causing death and reducing their chances of survival in their natural environment.
\end{abstract}

Palabras clave: desarrollo de anfibios, contaminación acuática, estrategias de conservación, Xochimilco.

\section{RESUMEN}

La población silvestre del ajolote mexicano (Ambystoma mexicanum) presenta un alarmante declive como consecuencia del deterioro de su medio ambiente: Xochimilco. El uso de pesticidas organofosforados (OF) en la región afecta la calidad del agua y es parcialmente responsable de dicho declive, lo cual puede deberse a la fragilidad del ajolote en etapas tempranas de su desarrollo, cuando se enfrenta a un medio contaminado con 
OF para sobrevivir. En este sentido, nuestro objetivo fue estudiar el efecto de los OF de grado comercial en el desarrollo temprano del ajolote, resaltando el contexto ambiental deteriorado. Los huevos fertilizados de este anfibio fueron expuestos a malatión (MLT), diclorvos (DVPP) y un grupo depurado en que se detuvo anticipadamente la exposición a los OF, así como un grupo control sin tratamiento. La eclosión, sobrevivencia, tamaño y forma de los organismos fueron monitoreados y analizados en la etapa embriónica y larval. Nuestros resultados muestran que los MLT y DVPP aceleran el tiempo de eclosión y la mortalidad aun después de remover los OF del medio. Los OF también son causantes de un tamaño reducido y una morfología anormal en los grupos tratados con pesticidas. Se propone que las mencionadas anormalidades propician condiciones adversas para la sobrevivencia del ajolote en su hábitat. Los resultados sugieren que los OF causan un daño irreversible en su embrión, deteniendo el desarrollo normal, ocasionando mortandad y reduciendo las probabilidades de éxito en su hábitat natural.

\section{INTRODUCTION}

The Mexican axolotl (Ambystoma mexicanum) is a neotenic urodele amphibian microendemic of the Mexican central region. A. mexicanum has been categorized as an endangered species by the Official Mexican Standard NOM-059-SEMARNAT-2010 (SEMARNAT 2010) and in critically endangered status by the International Union for Conservation of Nature (Zambrano et al. 2010). The alarming decline in the wild population density of $A$. mexicanum keep continues to be reported. According to the most recent census (2014), only $0.58 \%$ remains of the original population reported in the 1998 census (Voss et al. 2015).

The axolotl is endemic of the lacustrine area of Xochimilco, a water system between rural and urban areas characterized by canals, 'islands' called chinampas, and temporary wetlands affected by urbanization (Contreras et al. 2009, Ayala et al. 2019). Within this region, there are vast agricultural areas that are very important for the economic activity of the region (González-Carmona et al. 2014). As a consequence, the natural habitat of $A$. mexicanum is being highly impacted, especially by the use of pesticides that affect other non-target organisms and can contaminate soil and water (Aktar et al. 2009, Badii and Varela 2015).

The water quality in the Xochimilco canals has been compromised by the intensive application of organophosphorus pesticides (OPPs) to control plagues in croplands and the urban area (Robles-Mendoza et al. 2009, Mercado et al. 2015). Malathion (MLT) and dichlorvos (DDVP) are the most common OPPs in Mexico (Blanco-Jarvio et al. 2011, Mercado et al. 2015, Bejarano-González 2017). It has been reported that MLT concentrations in the Xochimilco water canals $(0.1 \mu \mathrm{g} / \mathrm{L})$ surpass those established by the U.S.
National Oceanic and Atmospheric Administration as indicators of chronic damage (Mercado-Borrayo et al. 2015). This implies a severe conservation issue for axolotls, whose survival is highly associated with water-quality parameters (Voss et al. 2015).

Therefore, we describe the detrimental effects of commercial-grade MLT and DVPP on the axolotl embryo survival, hatching period and early larvae size. Additionally, we contextualize the results in face of the direct impact of these pesticides in the axolotl habitat, regarding their conservation.

\section{MATERIALS AND METHODS}

Maintenance of eggs and larvae of $\boldsymbol{A}$. mexicanum

One clutch of 210 fertilized eggs of $A$. mexicanum was used to reduce variability among the experiments. The eggs were obtained during the months of September-October 2009 from the herpetology laboratory of the Facultad de Estudios Superiores Iztacala, Universidad Nacional Autónoma de México. The eggs and larvae were maintained in a medium consisting of $0.095 \mathrm{~g}$ of $\mathrm{NaHCO}_{3}, 0.06 \mathrm{~g}$ of $\mathrm{CaSO}_{4}$, $0.06 \mathrm{~g}$ of $\mathrm{MsSO}_{4}$, and $0.002 \mathrm{~g}$ of $\mathrm{KCl}$ in $1 \mathrm{~L} \mathrm{H}_{2} \mathrm{O}$ (Chaparro-Herrera et al. 2013). The experimental conditions corresponded to the season's environmental temperature and photoperiod; dissolved oxygen was maintained at saturation through an air pump. The temperature was measured daily in the morning before and after hatching. Hatched larvae were fed daily with Artemia nauplii.

\section{Pesticides exposure}

Commercial OPPs malathion $\left(\mathrm{C}_{10} \mathrm{H}_{19} \mathrm{O}_{6} \mathrm{PS}_{2} ; 57 \%\right.$ purity, MLT) and dichlorvos $\left(\mathrm{C}_{4} \mathrm{H}_{7} \mathrm{Cl}_{2} \mathrm{O}_{4} \mathrm{P} ; 76 \%\right.$ purity, DDVP) were obtained from El Semillero, Mexico. Commercial grade OPPs were chosen to 
evaluate formulations commonly used in the practice (as discussed below). Given the lack of information of commercial pesticides in relation to A. mexicanum, we used concentrations falling within the range of a similar report from Robles-Mendoza et al. (2009) using axolotls as a model, with the difference that they evaluated the effect of analytical grade OPPs and a maximum testing concentration of $30 \mathrm{mg} / \mathrm{L}$. The latter was done in order to gain novel understanding of the possible effects of commercial grade OPPs in the context of the current literature. Eggs of A. mexicanum of no more than $24 \mathrm{~h}$ post-fertilization (hpf) were exposed to three MLT concentrations (10 eggs per group in triplicate): $5.7,17.5$, and $5.7 \mathrm{mg} / \mathrm{L}$ for the depuration treatment (D); and to three DDPV treatment levels (10 eggs per group in triplicate): 1.5,1.9, and $1.9 \mathrm{mg} / \mathrm{L}$ for the depuration treatment (D). The solutions were prepared by diluting the correspondent OPP solution in an Environmentral Protection Agency (USEPA) medium. The control group was placed in EPA medium without OPPs. The depuration treatment consisted of exposing the embryos to OPPs only during the first $96 \mathrm{~h}$ of development. Following the exposure, the eggs were transferred to a clean EPA medium. The EPA medium with its respective treatment was replaced every $48 \mathrm{~h}$ in all groups.

\section{Embryo hatching monitoring and counting}

Egg hatching and survival, as well as larvae survival, were monitored daily excluding weekends. The embryo mortality was assessed when the eggs became pale-colored. Dead organisms were removed from the medium.

\section{Early larvae measuring and monitoring}

The size of hatched individuals was measured upon eclosion under a stereoscopic microscope (five animals per group). Early larvae were monitored daily until the 10th day post-hatching. Larvae mortality was considered after the animal became unresponsive to physical stimulus.

\section{Statistical analysis}

All data were analyzed using GraphPad prism v. 8.3 (San Diego, California USA, www.graphpad. com). Statistical significance was tested using $\chi^{2}$ with an $\alpha=0$, comparing the control (expected) against the treatments as a contingency table. The Levine's test for equality of variances did not meet the assumption of equality, hence a Kruskal-Wallis followed by a Dunn's test for multiple comparisons was performed where indicated in the results and figures.

\section{RESULTS}

\section{Organophosphorus pesticides (MLT and DDVP) induce early hatching and larvae mortality}

Embryo survival was defined as the embryo's ability to hatch. The temperature was recorded at $17^{\circ} \mathrm{C}$ on the morning of hatching, which was minimally affected in the group exposed to MLT at all concentrations. Of the organisms, $96.6 \%$ hatched in both the MLT 5.7 and $17.5 \mathrm{mg} / \mathrm{L}$ groups, and $90 \%$ in the $5.7 \mathrm{mg} / \mathrm{L}$ (D) group. Regarding DDVP, $60 \%$ of the organisms hatched in the $1.5 \mathrm{mg} / \mathrm{L}$ group, $66 \%$ in the $1.9 \mathrm{mg} / \mathrm{L}$ group, and $93.3 \%$ in the 1.5 $\mathrm{mg} / \mathrm{L}$ (D) group (Fig. 1a). The control group presented $100 \%$ of hatched organisms.

The hatching time was also recorded. The MLT and DDVP treated groups started to hatch at day 11 in high proportion; in contrast, the control group started to hatch until day 14. Thus, we grouped and compared each experimental group as early hatched individuals $(\leq 14 \mathrm{~d})$ and late hatched individuals $(\geq$ $14 \mathrm{~d}$ ). As a result, we observed that for all treatments except for MLT $5.7 \mathrm{mg} / \mathrm{L}$ (D), the development time until hatching was significantly faster than in the control group (Fig. 1b; $\chi^{2}, \mathrm{p}<0.0001$ ).

Next, we investigated the OPPs effect on early larvae mortality. The larvae could not survive under continuous exposure to MLT nor DDVP pesticides for a long period after hatching (Figs. 2a and 3a). On one hand, the MLT $17.5 \mathrm{mg} / \mathrm{L}$ mortality rate reached $100 \%$ at day 3, while in MLT $5.7 \mathrm{mg} / \mathrm{L}$ it reached $100 \%$ at day 5 (Fig. 2a). On the other hand, all DDVP groups reached $100 \%$ mortality by day 7 (Fig. 3a). When compared to the the control, all groups presented a significant difference in the dead vs alive rate on day $10\left(\chi^{2} \mathrm{p}<0.0001\right)$ (Figs. 2b and 3b).

In the case of MLT and DDVP depurated groups, mortality in both groups reached $100 \%$ after 5 and 7 days, respectively, suggesting that the effect of OPPs in early stages is irreversible, even at the smallest concentration tested.

\section{OPPs effect on larvae size and morphology}

After hatching, OPPs-treated larvae presented clear morphological abnormalities in contrast to the unexposed control group. The control group presented a straight elongated body, while both MLT and DDVP treated groups presented featured lordosis (Fig. 4a). Regarding size, the organisms presented a shorter body size in both OPP treatments. A Kruskal-Wallis test provided evidence of a significant difference $(\mathrm{p}<0.01)$ between the mean ranks. 

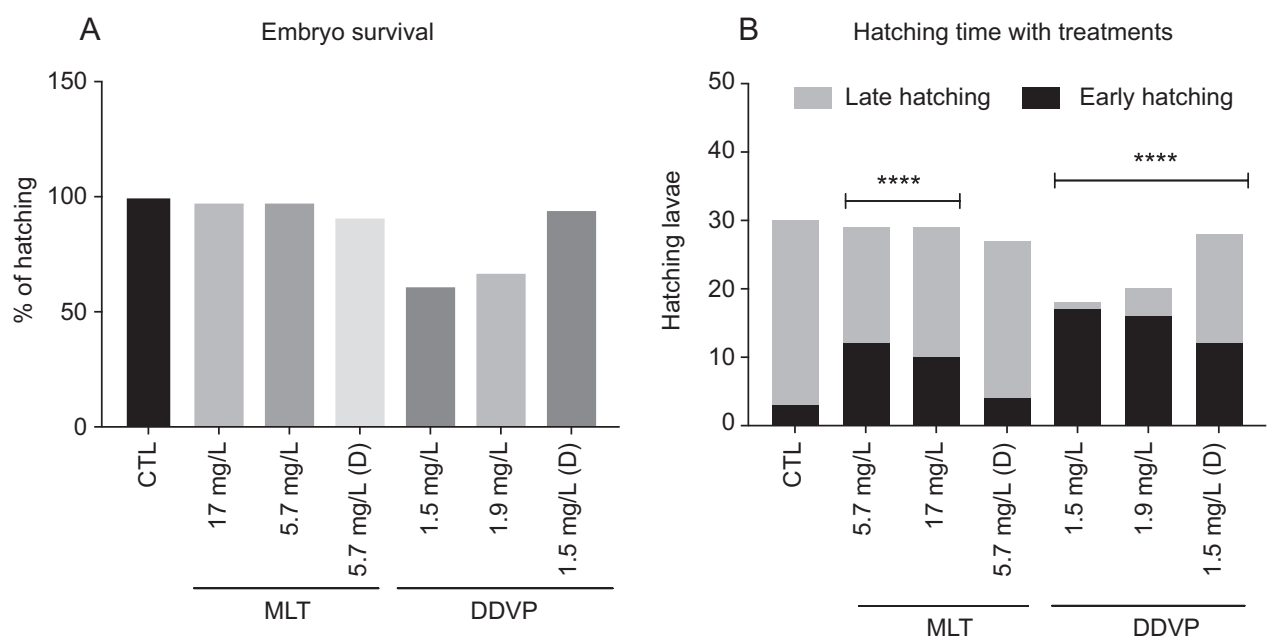

Fig. 1. Effects of organophosphorus pesticides on embryo survival(hatching).(a)Percentage of hatchedorganisms between the different concentrations of malathion and dichlorvos treatments. (b) Distribution of larvae that hatched early $(\leq 14 \mathrm{~d})$ or late $(\geq 14 \mathrm{~d})$ between the different treatments. $X^{2}(6,14)=54$, $* * * * \mathrm{p}<0.001$. CTL: control, MLT: malathion, DDVP: dichlorvos, (D): depurated.
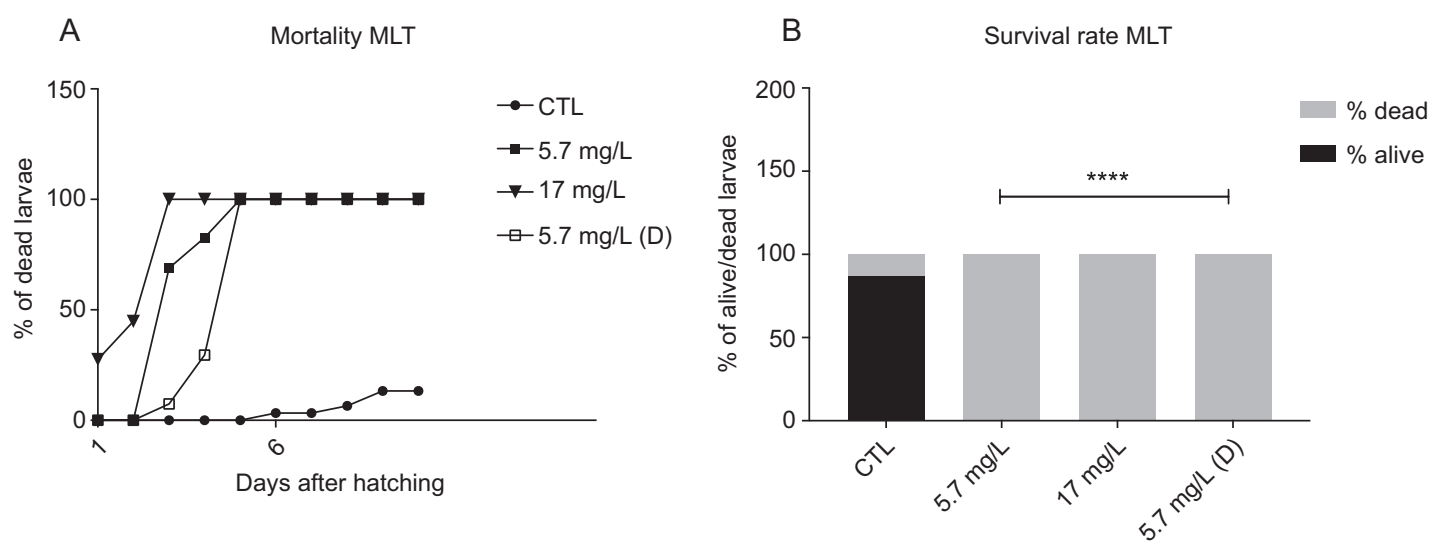

Fig. 2. Larvae mortality after exposure to malathion. (a) Percentage of dead larvae through days after hatching at different malathion concentrations $(\mathrm{mg} / \mathrm{L})$. (b) Rate of dead vs alive in percentage at different malathion concentrations $(\mathrm{mg} / \mathrm{L}) . \mathrm{X}^{2}(3,8)=333.5, * * * * \mathrm{p}<0.0001$. CTL: control, MLT: malathion, (D): depurated.

A

Mortality DDVP

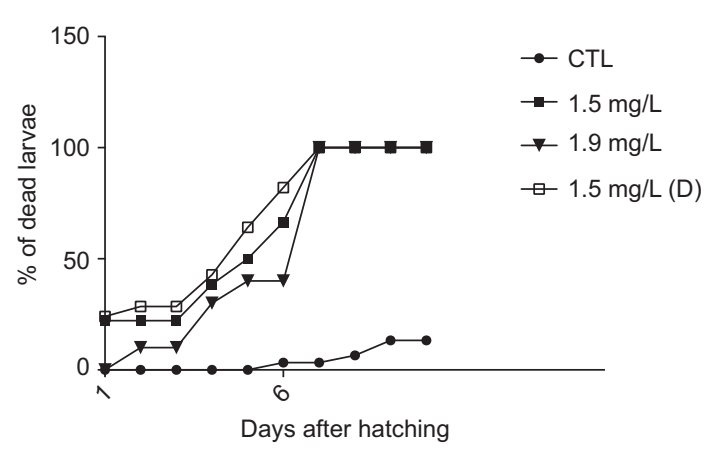

B Survival rate DDVP

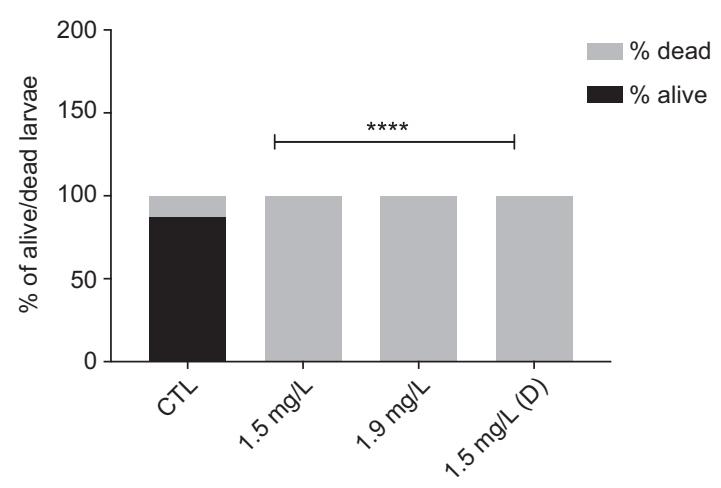

Fig. 3. Larvae mortality after exposure to dichlorvos. (a) Percentage of dead larvae through days after hatching at different dichlorvos concentrations $(\mathrm{mg} / \mathrm{L})$. (b) Rate of dead vs alive in percentage at different dichlorvos concentrations $(\mathrm{mg} / \mathrm{L}) . \mathrm{X}^{2}(3,8)=333.5, * * * * \mathrm{p}<0.0001$. CTL: control, DDVP: dichlorvos, (D): depurated. 


\section{A}
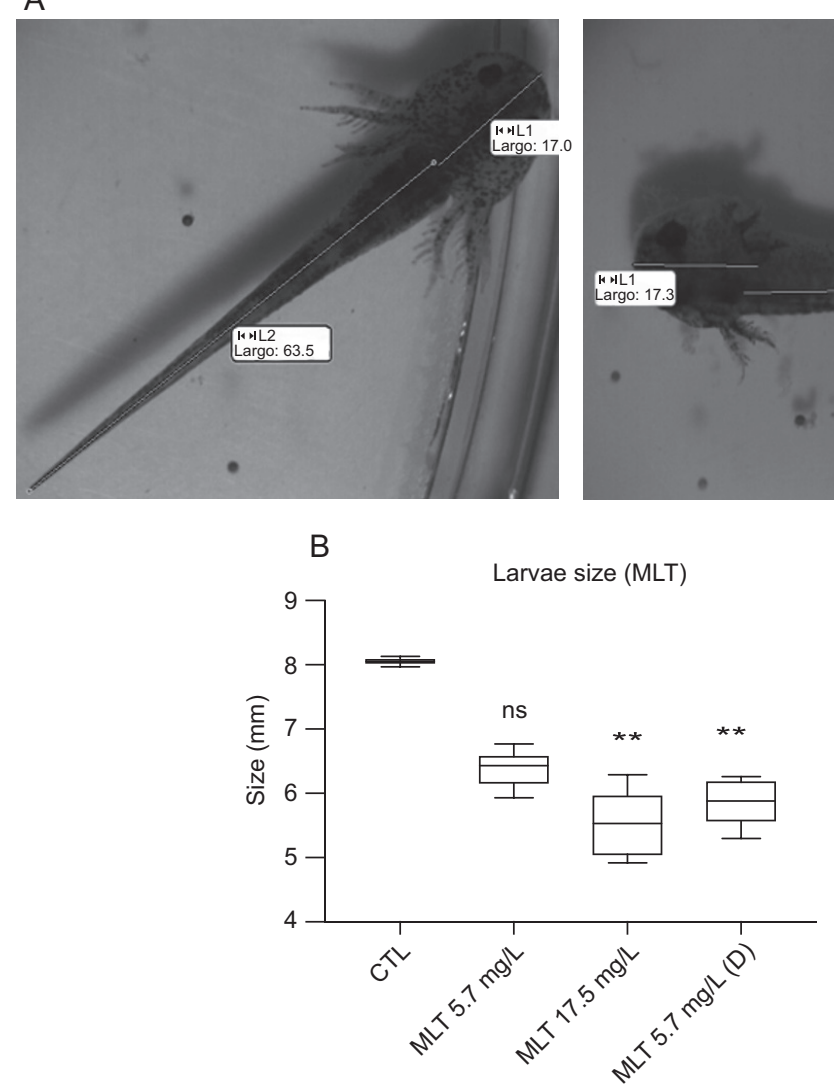
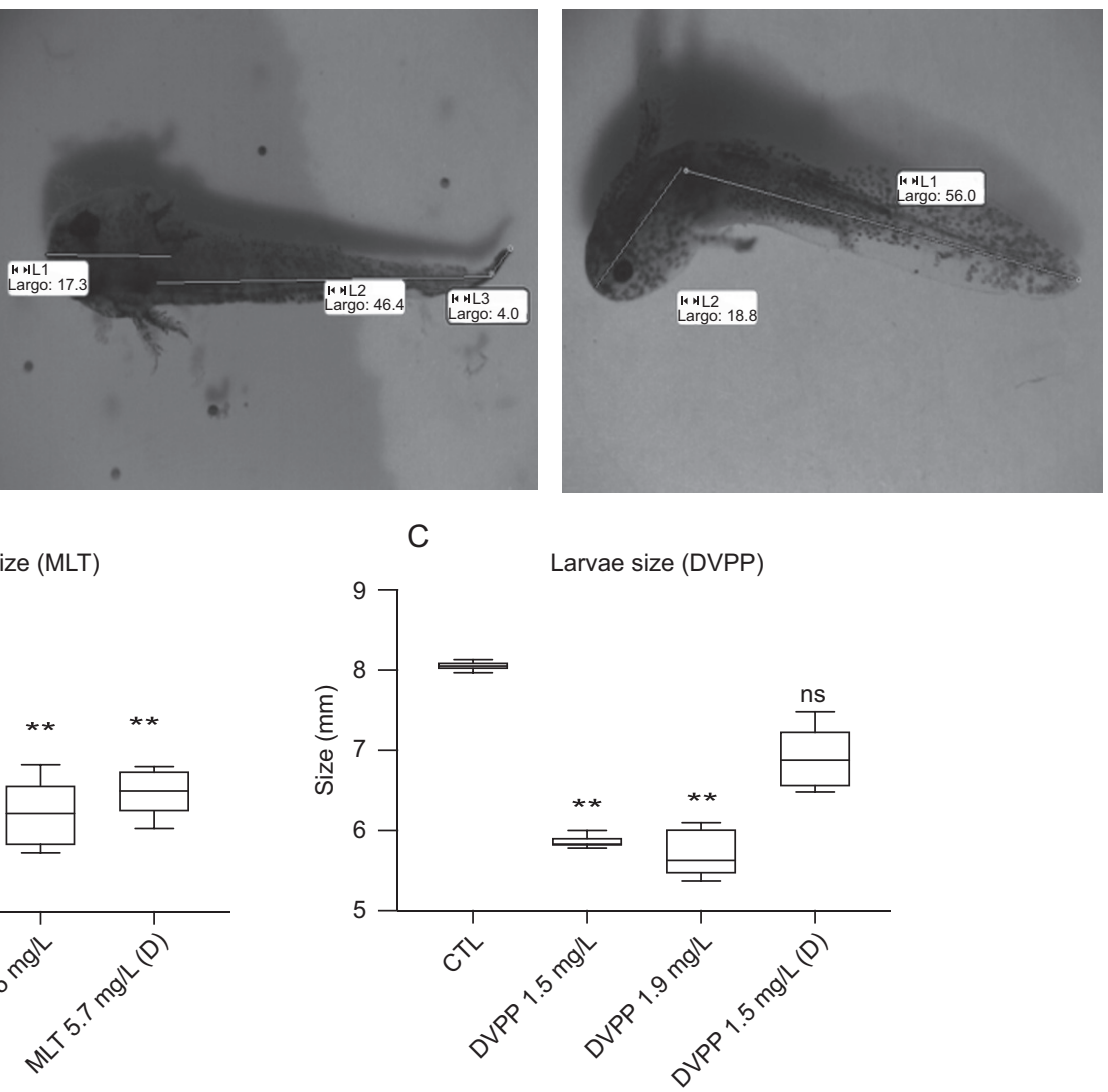

Fig. 4. Morphological abnormalities caused by organophosphorus pesticides. (a) Example of abnormal phenotype. (b, c) Larvae size in millimeters after treatments with different concentrations $(\mathrm{mg} / \mathrm{L})$ of malathion and dichlorvos, respectively $(\mathrm{n}=5)$. KrustalWallis followed by Dunn's test, ** $\mathrm{p}<0.01$. CTL: control, MLT: malathion, DDVP: dichlorvos, (D): depurated.

Dunn's pairwise test revealed a significant reduction in body size in the organisms treated with MLT $17.5 \mathrm{mg} / \mathrm{L}$ and $5.7 \mathrm{mg} / \mathrm{L}$ (D), DVPP $1.5 \mathrm{mg} / \mathrm{L}$ and DVPP $1.9 \mathrm{mg} / \mathrm{L}$ in comparison to the control group (Fig. 4b, c). Nevertheless, our data was not sufficient to provide evidence of differences between the treatments for both OPPs.

The results suggest that OPPs exposure from early developmental stages can cause an irreversible abnormal morphology as shown in larvae immediately after hatching.

\section{DISCUSSION}

The contribution of OPPs to the decline of several amphibian species including the axolotl has been reported in the literature (Slooff et al. 1983, Aktar et al. 2009). Despite these and other efforts to communicate the detrimental effects of pesticides, axolotl populations continue to decline in their natural habitats, tagging them as critically endangered (FríasÁlvarez et al. 2010) after more than 10 years from the first report on the effect of OPPs on A. mexicanum (Robles-Mendoza et al. 2009). In this study, we have recapitulated the effects of malathion, the most commonly used OPP, and dichlorvos, another widely used, persistent and toxic OPP. Most importantly, we have evaluated the effect of commercial-grade OPPs on $A$. mexicanum for the first time, in contrast with studies using analytical grade pesticides. The former would likely resemble better their effect in the wild.

In terms of the effects of OPP treatment at the embryo stage, our observations suggest that the exposure of eggs to MLT and DDVP causes only mild effects in the mortality rate, but affects significantly both the hatching time and larvae morphology, which is suggestive of an abnormal developmental process (as discussed below).

Seemingly, DVPP concentrations had a stronger effect in mortality, with a lowest survival rate of $60 \%$ (DVPP $1.9 \mathrm{mg} / \mathrm{L}$ ), while the lowest survival rate for 
MLT treatments (MLT $5.7 \mathrm{mg} / \mathrm{L}$ ) was $90 \%$. Only a few critical reports describe the embryo mortality rate in presence of OPPs or an unexposed control group. For instance, Chaparro-Herrera et al. (2013) reported a rate of $75 \%$ hatching in EPA medium conditions, while Robles-Mendoza et al. (2009) reported a $100 \%$ hatching rate in similar clean water conditions. The latter is identical to our observations for the control group. In the presence of OPPs, Robles-Mendoza et al. (2009) observed a much higher mortality rate when exposed to MLT, showing that even the lowest concentration in their study $(10 \mathrm{mg} / \mathrm{L})$ led to a $0 \%$ survival/hatching rate. In our experiments, the highest MLT concentration used was $17.5 \mathrm{mg} / \mathrm{L}$, which contrary to them, presented a survival rate of $90 \%$ in embryos.

It is important to highlight that commercial pesticides contain other components in their formulations that could affect their toxicity and therefore provide a more realistic scenario of their effects on the environment (Pereira et al. 2009). In this regard, conflicting evidence can be found in the literature in which analytical grade malathion has been reported to be more toxic than the commercial pesticide on Rana clamitans tadpoles (Puglis and Boone 2011), but less toxic when tested on Rana ribunda (Sayim 2008). It should be noted that the comparison of the mentioned reports should be taken with caution, because there are different species in different experimental set-ups. Similarly, our results of OPPs conditions cannot be accurately compared to those of Robles-Mendoza et al. (2009) due to the use of commercial pesticides in our experiments in contrast to the analytical grade pesticides in the mentioned study. Nevertheless, it is suggested that commercial grade pesticides could have a lesser detrimental effect in A. mexicanum.

In addition to the hatching efficiencies, we observed a severe effect of OPP treatments on the hatching time in comparison to the control group. Interestingly, some reports have shown the effect of pesticides on the hatching time of the Ambystoma genus, including the axolotl (Rohr et. al. 2003, Robles et al. 2009). Such reports indicate differences in the hatching time described as either delayed (Rohr et al. 2003) or early, similar to our study and the report from Robles-Mendoza et al. (2009). Altogether, these differences suggest that hatching of Ambystoma larvae depends on the pesticide they are exposed to, as well as the exposure time and the concentration used.

In relation to our results, the acceleration of the amphibian development (caused by unfavorable conditions) has been shown to carry physiological consequences that can translate into poor survival
(Gómez-Mestre et al. 2013). Although we did not seek to observe embryo malformation, we could suggest the presence of altered embryo development at the time of neurulation (i.e., neural fold closure and notochord formation) as observed previously with MLT (Robles-Mendoza et al. 2009). We can suggest a similar effect with DVPP, although it should be tested in the future.

As implied above, A. mexicanum hatching timing and survival depend on the environmental conditions. Interestingly, our experiments were performed at ambient conditions (temperature and photoperiod) during the months of September-October, which seemingly resulted in differences with the current literature. For instance, the hatching reported by Robles et al. (2009) started at day 9 (controlled temperature and photoperiod), while our control individuals started hatching at day 12. Furthermore, different survival/hatching percentage has been reported independently: $75 \%$ found by Chaparro-Herrera et al. (2013) in comparison to $100 \%$ observed by Robles et al. (2009) and $100 \%$ in the present report. This suggests mild differences in embryo timing that could be related to independent captivity environments (i.e., ambient temperature) (Chaparro-Herrera et al. 2018).

In our experiments, severe effects of OPPs were observed clearly in early larvae from treated organisms. All hatched MLT-treated eggs died 4 days post-hatching, even those who were in depuration, whereas larvae of DVPP-treated eggs survived until day 7 post-hatching, regardless of the depuration period. These results show the high susceptibility of axolotl embryos to commercial-grade OPPs. The mechanism of action of these pesticides is the inhibition of acetilcholinesterase, whose activity increases with development. Hence, it has been previously proposed that OPPs effect could be more adverse in larvae than embryos (Tahara et al. 2005, Arufe et al. 2007, Robles-Mendoza et al. 2009). Nevertheless, our results showed that even in eggs with a shortened exposure to OPPs, the removal of these compounds from the medium was not enough to increase survival in early larvae, suggesting important bioaccumulation in body tissues and irreversible damage early on. Further research should attempt to determine whether this effect is due to irreversible damage in axolotl embryos in a similar fashion to Sparus aurata in the larvae stage (Arufe et al. 2007) or is caused by OPPs prevalence (and continuous damage) in the tissue as observed in A. mexicanum elsewhere (de Llasera et al. 2009). The seemingly lack of effect of depuration (observed in the MLT depurated group) raises several concerns in conservation strategies that would 
need to consider effective bioremediation methods to increase survival opportunities.

Furthermore, early larvae presented morphological abnormalities and reduced size, as described previously in various amphibians including the axolotl (Bonfanti et al. 2004, Robles-Mendoza et al. 2009). Attribution to this trait has been given to an abnormal muscular myotomy structure, as a consequence of continuous action potentials occurring in the tail musculature, which leads to poor or abnormal reposition of muscle fibers during the development (Bonfanti et al. 2004, Colombo et al. 2005).

Noteworthy, an original report has shed light into realistic quantities of OPPs in the Xochimilco lake, ranging from non-detected to $2.7 \mu \mathrm{g} / \mathrm{L}$ of malathion in the water canals. These results in significant lower concentrations than those used in this and other reports in the $\mathrm{mg} / \mathrm{L}$ range (Mercado-Borrayo et al. 2015). Nevertheless, even realistic concentrations of OPPs such as chlorpyrifos have been shown damage to early axolotl larvae (Robles-Mendoza et al. 2011). Hence, it is proposed that future work should attempt to test realistic OPP quantities to better assess and recapitulate their possible effects in the axolotl habitat.

Importantly, the present study is, for the best of our knowledge, the first attempt to describe the effect of DVPP on the embryo stage of a urodele amphibian species. Previous reports from anuran tadpoles support the detrimental effect of DVPP observed in the present study (Geng et al. 2005).

Efforts should be made to link ours and others laboratory observations to explain plausible scenarios of $A$. mexicanum disappearance from its natural environment, in order to help conservation strategies. For instance, suitable areas preferred by the species are in the local areas used for traditional agriculture (Contreras et al. 2009). Adding to these observations, microhabitat preferences have been proposed to explain the failure of efforts to ensure axolotl survival and conservation over the past years (Ayala et al. 2019).

For instance, Ortiz-Ordóñez et al. (2016) showed that sediment elutriates from Xochimilco lake were a source of pollutant accumulation with the ability to cause damage at biochemical, cellular and organic levels on A. mexicanum. Considering that axolotls often lay their eggs on the substrate (Chaparro-Herrera et al. 2013), it is likely that the accumulation of OPPs in the sediment contributes to the poor survival and conservation of the species.

Finally, although pesticides are used to control pests, their application can generate damages and alterations to any exposed organism. Axolotls could be considered as a model for the study of teratogenesis, the alteration of reproduction and development in humans when exposed to these pesticides (Eskenazi et al. 2007).

\section{CONCLUSION}

We have presented an analysis of the effect of MLT and DVPP on the survival, hatching, and morphology of axolotl in early stages, recapitulating previous reports describing the effects of the former, as well as reporting for the first time the effects of the latter in the axolotl embryo. The effects of these pesticides in early larvae size, sparsely described in previous reports, was included. Additionally, we analyzed such results in the context of the $A$. mexicanum habitat and how it could have partially influenced the dramatic population descent observed over time. It is relevant to take immediate conservation and restoration actions, in order to maintain the axolotl population in its natural habitat, as well as eco-friendly agriculture practices.

\section{ACKNOWLEDGMENTS}

The authors would like to acknowledge the Laboratory of Herpetology (vivarium) as well as the scientific research module of the biology program at the Facultad de Estudios Superiores Iztacala, UNAM.

\section{REFERENCES}

Aktar M.W., Sengupta D. and Chowdhury A. (2009). Impact of pesticides use in agriculture: Their benefits and hazards. Interdiscip. Toxicol. 2 (1), 1-12. https:// doi.org/10.2478/v10102-009-0001-7

Arufe M.I., Arellano J.M., García L., Albendín G. and Sarasquete C. (2007). Cholinesterase activity in gilthead seabream (Sparus aurata) larvae: Characterization and sensitivity to the organophosphate azinphosmethyl. Aquat. Toxicol. 84 (3), 328-336. https://doi. org/10.1016/j.aquatox.2007.06.009

Ayala C., Ramos G., A., Merlo Á. and Zambrano L. (2019). Microhabitat selection of axolotls, Ambystoma mexicanum, in artificial and natural aquatic systems. Hidrobiologia 828, 11-20. https://doi.org/10.1007/ s10750-018-3792-8

Badii H.M. and Varela S. (2015). Insecticidas organofosforados: effectos sobre la salud y el ambiente. Cultura Científica y Tecnológica 5 (28), 5-17. 
Bejarano-González F. (2017). Los plaguicidas altamente peligrosos en México. Red de Acción sobre Plaguicidas y Alternativas en México (RAPAM), Estado de México, México, $251 \mathrm{pp}$.

Blanco-Jarvio A., Chávez-López C., Luna-Guido M., Dendooven L. and Cabirol N. (2011). Denitrification in a chinampa soil of Mexico City as affected by methylparathion: A laboratory study. Eur. J. Soil. Biol. 47 (5), 271-278. https://doi.org/10.1016/j. ejsobi.2011.06.003

Bonfanti P., Colombo A., Orsi F., Nizzetto I. andrioletti M., Bacchetta R., Mantecca P., Fascio U., Vailati G. and Vismara C. (2004). Comparative teratogenicity of Chlorpyrifos and Malathion on Xenopus laevis development. Aquat. Toxicol. 70 (3), 189-200. https://doi. org/10.1016/j.aquatox.2004.09.007

Chaparro-Herrera D.J., Nandini S. and Sarma S.S.S. (2013). Effect of water quality on the feeding ecology of axolotl Ambystoma mexicanum. J. Limnol. 72 (3), 555-563. https://doi.org/10.4081/jlimnol.2013.e46

Chaparro-Herrera D.J., Arias-Balderas S.F., CorreaSánchez F., Rivera-Velázquez R. and Ramírez-García P. (2018). Factors of global warming (UV-B radiation and temperature) affecting larval development of Ambystoma granulosum. Teoria y Praxis 25, 131-154.

Colombo A., Orsi F. and Bonfanti P. (2005). Exposure to the organophosphorus pesticide chlorpyrifos inhibits acetylcholinesterase activity and affects muscular integrity in Xenopus laevis larvae. Chemosphere 61 (11), 1665-1671. https://doi.org/10.1016/j.chemosphere.2005.04.005

Contreras V., Martínez-Meyer E., Valiente E. and Zambrano L. (2009). Recent decline and potential distribution in the last remnant area of the microendemic Mexican axolotl (Ambystoma mexicanum). Biol. Conserv. 142 (12), 2881-2885. https://doi.org/10.1016/j. biocon.2009.07.008

De Llasera M.P.G., Cruz-Reyes L. and Vera-Ávila L.E. (2009). A method for the analysis of organophosphorus pesticide residues in Mexican axolotl. J. Environ. Sci. Health B 45 (1), 25-32. https://doi. org/10.1080/03601230903404309

Eskenazi B., Marks A.R., Bradman A., Harley K., Barr D.B., Johnson C., Morga N. and Jewell N.P. (2007). Organophosphate pesticide exposure and neurodevelopment in young Mexican-American children. Environ. Health Perspect. 115 (5), 792-798. https:// doi.org/10.1289/ehp.9828

Frías-Álvarez P., Zúñiga-Vega J. and Flores-Villela O. (2010). A general assessment of the conservation status and decline trends of Mexican amphibians. Biodivers. Conserv. 19 (13), 3699-3742. https://doi.org/10.1007/ s10531-010-9923-9
Geng B.R., Yao D. and Xue Q.Q. (2005). Acute toxicity of the pesticide dichlorvos and the herbicide butachlor to tadpoles of four anuran species. B. Environ. Contam. Tox. 75 (2), 343-349. https://doi.org/10.1007/s00128005-0759-z

Gómez-Mestre I., Kulkarni S. and Buchholz D.R. (2013). Mechanisms and consequences of developmental acceleration in tadpoles responding to pond drying. Plos One 8 (12), e84266. https://doi.org/10.1371/journal. pone. 0084266

González-Carmona E. and Torres-Valladares C.I. (2014). La sustentabilidad agrícola de las chinampas en el valle de México: caso Xochimilco. Revista Mexicana de Agronegocios 34 (18), 699-709.

Mercado-Borrayo B.M., Cram Heydrich S., Rosas Pérez I., Hernández Quiroz M. and Ponce de León-Hill C. (2015). Organophosphorus and organochlorine pesticides bioaccumulation by Eichhornia crassipes in irrigation canals in an urban agricultural system. Int. J. Phytoremediat. 17 (7), 701-708. https://doi.org/10. 1080/15226514.2014.964841

Ortiz-Ordóñez E., López-López E., Sedeño-Díaz J.E., Uría E., Morales I.A., Pérez M.E. and Shibayama M. (2016). Liver histological changes and lipid peroxidation in the amphibian Ambystoma mexicanum induced by sediment elutriates from the lake Xochimilco. J. of Environ. Sci. 46 (C), 156-164. https://doi.org/10.1016/j. jes.2015.06.020

Pereira J.L., Antunes S.C., Castro B.B., Catarina R.M., Gonçalves A.M.M., Gonçlaves F. and Pereira R. (2009). Toxicity evaluation of three pesticides on non-target aquatic and soil organisms: commercial formulation versus active ingredient. Ecotoxicology 18, 455-463. https://doi.org/10.1007/s10646-009-0300-y

Robles-Mendoza C., García-Basilio C., Cram-Heydrich S., Hernández-Quiroz M. and Vanegas-Pérez C. (2009). Organophosphorus pesticides effect on early stages of the axolotl Ambystoma mexicanum (Amphibia: Caudata). Chemosphere 74 (5), 703-710. https://doi. org/10.1016/j.chemosphere.2008.09.087

Robles-Mendoza C., Zúñiga-Lagunes S.R., Ponce de León-Hill C.A., Hernández-Soto J. and Vanegas-Pérez C. (2011). Esterases activity in the axolotl Ambystoma mexicanum exposed to chlorpyrifos and its implication to motor activity. Aquat. Toxicol. 105 (3), 728-734. https://doi.org/10.1016/j.aquatox.2011.09.001

Rohr R.J., Elskus A.A., Shepherd B.S., Crowley H.P., McCarthy M.T., Niedzwiecki H.J., Sager T., Sih A. and Palmer D.B. (2003). Lethal and sublethal effects of atrazine, carbaryl, endosulfan, and octylphenol on the streamside salamander (Ambystoma barbouri). Environ. Toxicol. Chem. 22 (10), 2385-2392. https:// doi.org/10.1897/02-528 
Puglis H. and Boone M. (2011). Effects of technical-grade active ingredient vs commercial formulation of seven pesticides in the presence or absence of UV radiation on survival of green frog tadpoles. Arch. Environ. Contam. Toxicol. 60, 145-155. https://doi.org/10.1007/ s00244-010-9528-Z

Sayim F. (2008). Acute toxic effects of malathion on the $21^{\text {st }}$ stage larvae of the marsh frog. Turk. J. Zool. 32, 99-106

SEMARNAT (2010). Norma Oficial Mexicana NOM059-SEMARNAT-2010. Protección ambientalEspecies nativas de México de flora y fauna silvestres-Categorías de riesgo y especificaciones para su inclusión, exclusión o cambio-Lista de especies en riesgo. Secretaría de Medio Ambiente y Recursos Naturales. Diario oficial de la federación, 30 de diciembre.
Slooff W., Canton J.H. and Hermens J.L.M. (1983). Comparison of the susceptibility of 22 freshwater species to 15 chemical compounds. I. (Sub) acute toxicity tests. Aquat. Toxicol. 4 (2), 113-128. https:// doi.org/10.1016/0166-445X(83)90049-8

Tahara M., Kubota R., Nakazawa H., Tokunaga H. and Nishimura T. (2005). Use of cholinesterase activity as an indicator for the effects of combinations of organophosphorus pesticides in water from environmental sources. Water Res. 39 (20), 5112-5118. https://doi. org/10.1016/j.watres.2005.09.042

Voss S.R., Woodcock M.R. and Zambrano L. (2015). A tale of two axolotls. BioScience 65 (12), 1134-1140. https://doi.org/10.1093/biosci/biv153

Zambrano L., Mosig-Reidl P., Mckay J., Griffiths R., Shaffer B., Flores-Villela O. and Wake D. (2010). Ambystoma mexicanum. The IUCN Red List of Threatened Species 2010, e.T1095A3229615. https://doi.org/10.2305/ IUCN.UK.2010-2.RLTS.T1095A3229615.en 